\title{
PENGARUH GAYA KEPEMIMPINAN TRANSFORMASIONAL, BUDAYA ORGANISASI DAN MOTIVASI EKSTRINSIK TERHADAP KINERJA KARYAWAN PT SEMEN PADANG, JAKARTA SELATAN
}

\author{
Edi Sugiono ${ }^{1}$ \\ Widia Rachmawati ${ }^{2}$ \\ ${ }^{1,2}$ Fakultas Ekonomi dan Bisnis Universitas Nasional
}

Email: edisugiono33@yahoo.com ${ }^{1}$, widiarachmawati80@gmail.com ${ }^{2}$

\begin{abstract}
ABSTRAK
Penelitian ini bertujuan untuk menganalisis pengaruh gaya kepemimpinan transformasional, budaya organisasi dan motivasi ekstrinsik terhadap kinerja karyawan PT Semen Padang, Jakarta Selatan. Data yang digunakan dalam penelitian ini adalah data primer yang diperoleh dari penyebaran kuesioner kepada 102 orang karyawan PT Semen Padang, Jakarta Selatan sebagai responden. Analisis yang digunakan adalah analisis inferensial dengan menggunakan regresi linear berganda. Hasil penelitian menunjukkan bahwa gaya kepemimpinan transformasional, budaya organisasi dan motivasi ekstrinsik secara parsial berpengaruh positif dan signifikan terhadap kinerja karyawan.
\end{abstract}

Kata kunci: Gaya kepemimpinan transformasional, budaya organisasi, motivasi ekstrinsik, kinerja karyawan

ABSTRACT
This study aims to analyze the influence of transformational leadership style, organizational culture and extrinsic motivation on employee performance of PT Semen Padang, Jakarta Selatan. The data used in this study is primary data that obtained from questionnaires distribution to 102 employees of PT Semen Padang, South Jakarta as respondents. The analysis used is inferential analysis by multiple linear regression. Results of the study showed that tranformational leadership style, organizational culture and extrinsic motivation partially has positive and significant effect on employee performance of PT Semen Padang, Jakarta Selatan.

Keyword: Transformational leadership style, organizational culture, extrinsic motivation, employee performance

\section{PENDAHULUAN}

Setiap perusahaan perlu senantiasa meningkatkan kinerja karyawannya secara terus-menerus dan berkelanjutan karena setiap karyawan tersebut berperan penting dalam setiap perencanaan, pengorganisasian, pelaksanaan dan pengendalian berbagai strategi lintas fungsional dalam upaya untuk mencapai visi, misi dan tujuan yang telah ditetapkan. Perusahaan dapat menggunakan berbagai variabel yang signifikan untuk meningkatkan kinerja karyawannya.

PT Semen Padang merupakan pabrik semen pertama di Indonesia yang didirikan pada tahun 1910 dengan nama NV Nederlandsch Indische Portland Cement Maatschappij (Semen Padang, 2018). Sebagai perusahaan yang memiliki histori yang panjang di sektor konstruksi di Indonesia, PT Semen Padang telah menunjukkan kinerja yang cukup baik 
dari tahun ke tahun. Tetapi berdasarkan data internal, persentase realisasi pencapaian dan/atau pemenangan tender oleh perusahaan tersebut cenderung berfluktuasi selama lima tahun terakhir. Selain itu, persentase realisasi kinerja PT Semen Padang, Jakarta Selatan sebagai salah satu cabang dari PT Semen Padang itu sendiri cenderung berfluktuasi selama tiga tahun terakhir di berbagai departemen. Bahkan, terjadi penurunan realisasi pencapaian kinerja di beberapa departemen tertentu. Hal ini perlu segera ditanggapi secara serius dalam rangka mencegah terjadinya kembali penurunan persentase realisasi pencapaian kinerja dari setiap departemen di dalam perusahaan pada periode mendatang. Perusahaan bahkan perlu berupaya untuk meningkatkan kinerja karyawannya dalam rangka meningkatkan kinerja perusahaan itu sendiri secara keseluruhan.

Perusahaan dapat menggunakan berbagai variabel yang signifikan untuk meningkatkan kinerja karyawannya. Salah satunya adalah variabel gaya kepemimpinan transformasional. Hasil penelitian yang dilakukan oleh Mubarak dan Darmanto (2015) serta Subhi dan Yuniati (2014) telah membuktikan bahwa gaya kepemimpinan transformasional berpengaruh positif dan signifikan terhadap kinerja karyawan. Hal tersebut terjadi karena pemimpin dengan gaya kepemimpinan transformasional cenderung akan memberikan lebih banyak kesempatan bagi karyawannya untuk berkreasi melalui otonomi (Khan, et al., 2012). Sugiono dan Pratista (2018) mengemukakan bahwa pemberian kesempatan yang lebih banyak kepada karyawan untuk berkreasi akan menyebabkan karyawan tersebut menjadi lebih mampu untuk menciptakan dan mengembangkan gagasannya untuk kepentingan perusahaan, sehingga karyawan tersebut akan memberikan kontribusi yang lebih besar kepada perusahaan tersebut. Akibatnya, kinerja karyawan tersebut pun akan mengalami peningkatan.

Variabel lain yang dapat digunakan sebagai alat peningkatan kinerja karyawan adalah variabel budaya organisasi. Maharani dan Efendi (2017), Warni (2014), serta Suryadi dan Efendi (2018) telah membuktikan bahwa budaya organisasi berpengaruh positif dan signifikan terhadap kinerja karyawan. Menurut Sutrisno (2010), budaya yang dikelola dengan benar sebagai alat manajemen akan dapat mempengaruhi karyawan dan mendorongnya untuk bersikap positif, dedikatif dan produktif, sehingga meskipun nilainilai budaya tersebut tidak terlihat, tetapi keberadaannya merupakan kekuatan yang mengarahkan perilaku karyawan untuk berkinerja secara efektif.

Selain gaya kepemimpinan transformasional dan budaya organisasi, motivasi ekstrinsik juga dapat digunakan sebagai variabel untuk meningkatkan kinerja karyawan. Oleh karena temuan Ayer, dkk., (2016), Rizwan et al. (2014), serta Sutanto dan Ariyanto 
(2018) menunjukkan bahwa motivasi kerja berpengaruh positif dan signifikan terhadap kinerja karyawan, maka motivasi ekstrinsik sebagai bagian dari motivasi kerja itu sendiri diyakini juga memiliki pengaruh yang positif dan signifikan terhadap kinerja karyawan. Hal ini didukung oleh Manullang (2001) yang menyatakan bahwa tingkat kemangkiran karyawan akan mengalami peningkatan pada perusahaan yang tidak memberikan motivasi ekstrinsik yang sepadan kepada karyawannya, misalnya dalam bentuk kondisi kerja, upah, tunjangan dan/atau jaminan keselamatan kerja yang memadai. Hal tersebut akan menyebabkan terjadinya penurunan kinerja karyawan, sehingga motivasi ekstrinsik disimpulkan memiliki pengaruh yang positif dan signifikan terhadap kinerja karyawan.

Berdasarkan latar belakang tersebut, perlu dilakukan penelitian untuk menganalisis pengaruh gaya kepemimpinan transformasional, budaya organisasi dan motivasi ekstrinsik terhadap kinerja karyawan PT Semen Padang, Jakarta Selatan.

\section{TINJAUAN PUSTAKA}

\section{Gaya Kepemimpinan Transformasional}

Gaya kepemimpinan adalah suatu pola tingkah laku dari seorang pemimpin yang berkaitan dengan kemampuannya untuk memimpin (Moeheriono, 2012:386). Gaya kepemimpinan juga dapat diartikan sebagai sekumpulan ciri dari seorang pimpinan dalam mempengaruhi bawahannya untuk mencapai sasaran tertentu yang telah ditetapkan oleh organisasi yang bersangkutan (Rivai dan Mulyadi, 2012:42).

Gaya kepemimpinan transformasional adalah gaya kepemimpinan yang menginspirasi para pengikutnya untuk melampaui kepentingan pribadi mereka dengan memberikan efek yang mendalam dan luar biasa bagi para pengikutnya tersebut (Robbins dan Judge, 2008). Menurut Mondiani (2012:47), kepemimpinan transformasional merupakan kemampuan seorang pemimpin dalam menginspirasi dan memotivasi para pengikutnya untuk meningkatkan hasil yang dicapainya. Khan, et al. (2012) mengemukakan bahwa pengikut di bawah gaya kepemimpinan transformasional cenderung diberikan lebih banyak kebebasan, rasa kepemilikan dan tanggung jawab yang akan mendorong tercapainya tujuan perusahaan yang bersangkutan.

Menurut Bass dan Avolio (1994) dalam Yukl (2010:305), kepemimpinan transformasional memiliki empat dimensi berikut.

1) Karisma, yaitu perilaku pemimpin yang menimbulkan rasa kagum, hormat dan percaya pada para pengikutnya. 
2) Motivasi yang menginspirasi, yaitu kemampuan pemimpin untuk mengartikulasikan secara jelas prestasi yang diharapkan dari para pengikutnya, menunjukkan komitmennya terkait tujuan organisasi, serta membangun semangat dari timnya dengan cara menumbuhkan antusiasme dan optimisme.

3) Stimulasi intelektual, yaitu perilaku pemimpin dalam menciptakan berbagai ide baru, memberikan solusi terhadap masalah yang dihadapi oleh para pengikutnya dan memotivasi pengikutnya dalam upaya pencarian pendekatan baru yang dapat digunakan untuk menjalankan berbagai tugas dari organisasi yang dipimpinnya.

4) Perhatian secara individual, yaitu kemauan pemimpin untuk memperhatikan setiap saran yang diberikan oleh para pengikutnya serta memperhatikan setiap pengembangan karir yang dibutuhkan oleh pengikutnya tersebut.

\section{Budaya Organisasi}

Sunyoto (2012:225) mendefinisikan budaya organisasi sebagai suatu sistem yang dianut secara bersama-sama oleh anggota dari suatu organisasi. Menurut Sutrisno (2010), budaya organisasi adalah suatu sistem yang terdiri dari seperangkat nilai, keyakinan, asumsi dan norma yang diberlakukan dalam suatu organisasi sebagai pedoman perilaku bagi anggotanya serta sebagai solusi atas berbagai masalah yang melibatkan organisasi tersebut.

Adapun menurut Moeheriono (2012:338), fungsi dari budaya organisasi antara lain mencakup hal-hal sebagai berikut.

1) Memberikan identitas organisasi bagi karyawannya.

2) Memudahkan pembentukan komitmen secara kolektif yang mencerminkan kebanggaan karyawan sebagai bagian dari suatu organisasi.

3) Mempromosikan stabilitas sistem sosial yang mencerminkan lingkungan kerja yang positif dan suportif, serta pengaturan konflik dan berbagai perubahan secara efektif.

Menurut Denison (1990), budaya organisasi memiliki empat dimensi sebagai berikut.

1) Keterlibatan (involvement), yakni keterlibatan karyawan dalam suatu organisasi yang menciptakan rasa memiliki dan tanggung jawab karyawan tersebut terhadap organisasi yang bersangkutan.

2) Konsistensi (consistency), yakni suatu dimensi yang merupakan sumber utama dari kontrol yang terintegrasi dan terkoordinasi. 
3) Adaptabilitas (adaptability), yakni kemampuan organisasi dalam menerima perubahan untuk kemudian diinterpretasikan dan diterjemahkan ke dalam perubahan perilaku internal berdasarkan suatu norma dan kepercayaan tertentu.

4) Misi (mission), yakni arah dan sasaran yang secara jelas mendefinisikan tujuan dari suatu organisasi melalui suatu perencanaan strategis yang menunjukkan visi organisasi tersebut di masa mendatang.

\section{Motivasi Ekstrinsik}

Motivasi adalah suatu kondisi yang menimbulkan dorongan bagi seseorang untuk menjalankan tugasnya sesuai dengan fungsi yang ditetapkan dalam organisasi yang bersangkutan (Bangun, 2012:312). Hasibuan (2012) mengartikan motivasi sebagai sebagai suatu proses untuk menciptakan gairah kerja bagi pegawai yang menggerakkannya untuk bekerja sama dan bekerja efektif secara terintegrasi untuk mencapai kepuasan tertentu.

Sardiman (2005:89) mengklasifikasikan motivasi ke dalam dua jenis, yaitu: (1) motivasi intrinsik dan motivasi ekstrinsik. Menurut Sardiman (2005:89), motivasi intrinsik adalah motif penggerak yang aktivasinya tidak perlu dirangsang dari luar, karena setiap individu telah memilikinya di dalam dirinya masing-masing. Sementara itu, motivasi ekstrinsik didefinisikan oleh Supandi (2011:61) sebagai suatu motivasi yang ditimbulkan oleh rangsangan yang berasal dari luar individu.

Menurut Herzberg dalam Luthans (2011), motivasi ekstrinsik dapat diindikasikan oleh beberapa indikator, yaitu: (1) kebijakan dan administrasi (policy and administration), (2) kualitas supervisi (supervisor quality), (3) hubungan antarpribadi (interpersonal relation), (4) kondisi kerja (working condition), dan (5) gaji (wages).

\section{Kinerja Karyawan}

Kinerja sumber daya manusia merupakan prestasi kerja yang dicapai oleh seseorang. Kinerja juga dapat diartikan sebagai kualitas dan kuantitas dari hasil pekerjaan yang dilakukan oleh karyawan sesuai dengan standar kerja tertentu yang telah ditetapkan oleh perusahaan (Mangkunegara, 2011). Menurut Bangun (2012), kinerja adalah suatu hasil yang diraih dari suatu pekerjaan berdasarkan serangkaian syarat kerja tertentu.

Menurut Pasolong (2010:186), kinerja dapat dipengaruhi oleh faktor-faktor sebagai berikut.

1) Kemampuan, yaitu kemampuan di suatu bidang tertentu yang dipengaruhi oleh bakat, minat dan kecerdasan yang cukup. 
2) Kemauan, yaitu kemauan untuk melakukan berbagai upaya di tingkatan tertentu yang tinggi untuk mencapai tujuan organisai,

3) Energi, yaitu sumber kekuatan yang dimiliki oleh seseorang di dalam dirinya.

4) Teknologi, yaitu penerapan pengetahuan untuk memudahkan pelaksanaan pekerjaan.

5) Kompensasi, yaitu balas jasa bermanfaat yang diterima oleh karyawan atas kinerja yang dihasilkannya.

6) Kejelasan tujuan, yaitu rumusan jelas mengenai tujuan yang dituntut untuk dicapai oleh karyawan.

7) Keamanan, yaitu kebutuhan fundamental yang ditujukan agar karyawan merasa aman dalam menjalankan pekerjaannya.

\section{Pengaruh Gaya Kepeminpinan Transformasional terhadap Kinerja Karyawan}

Pemimpin dengan gaya kepemimpinan transformasional cenderung akan memberikan lebih banyak kesempatan bagi karyawannya untuk berkreasi melalui otonomi karena pemimpin dengan gaya ini cenderung lebih fleksibel daripada pemimpin dengan gaya kepemimpinan lainnya (Khan, et al., 2012). Sugiono dan Pratista (2018) mengemukakan bahwa pemberian kesempatan yang lebih banyak kepada karyawan untuk berkreasi akan menyebabkan karyawan tersebut menjadi lebih mampu untuk menciptakan dan mengembangkan gagasannya untuk kepentingan perusahaan, sehingga karyawan tersebut akan memberikan kontribusi yang lebih besar kepada perusahaan tersebut. Akibatnya, kinerja karyawan tersebut pun akan mengalami peningkatan. Sejalan dengan uraian tersebut, hasil penelitian yang dilakukan oleh Mubarak dan Darmanto (2015), Subhi dan Yuniati (2014), serta Sugiono dan Pratista (2018) juga telah membuktikan adanya pengaruh yang positif dan signifikan dari gaya kepemimpinan transformasional terhadap kinerja karyawan.

$\mathrm{H}_{1}$ : Gaya Kepemimpinan transformasional berpengaruh positif dan signifikan terhadap kinerja karyawan PT Semen Padang, Jakarta Selatan

\section{Pengaruh Budaya Organisasi terhadap Kinerja Karyawan}

Sutrisno (2010) mengemukakan bahwa budaya yang dikelola dengan benar sebagai alat manajemen akan dapat mempengaruhi karyawan dan mendorongnya untuk bersikap positif, dedikatif dan produktif, sehingga meskipun nilai-nilai budaya tersebut tidak terlihat, tetapi keberadaannya merupakan kekuatan yang mengarahkan perilaku karyawan untuk berkinerja secara efektif. Hal tersebut sejalan dengan hasil penelitian yang dilakukan 
oleh Maharani dan Efendi (2017), Warni (2014), serta Suryadi dan Efendi (2018) yang menunjukkan bahwa budaya organisasi berpengaruh positif dan signifikan terhadap kinerja karyawan, sehingga semakin baik budaya dalam suatu organisasi, maka semakin baik pula kinerja dari karyawan yang bekerja di organisasi tersebut.

$\mathrm{H}_{2}$ : Budaya organisasi berpengaruh positif dan signifikan terhadap kinerja karyawan PT Semen Padang, Jakarta Selatan

\section{Pengaruh Motivasi Ekstrinsik terhadap Kinerja Karyawan}

Menurut Manullang (2001), tingkat kemangkiran karyawan akan mengalami peningkatan pada perusahaan yang tidak memberikan motivasi ekstrinsik yang sepadan kepada karyawannya, misalnya dalam bentuk kondisi kerja, upah, tunjangan dan/atau jaminan keselamatan kerja yang memadai. Hal tersebut akan menyebabkan terjadinya penurunan kinerja karyawan, sehingga motivasi ekstrinsik disimpulkan memiliki pengaruh yang positif dan signifikan terhadap kinerja karyawan. Oleh karena temuan Ayer, dkk., (2016), Rizwan et al. (2014), serta Sutanto dan Ariyanto (2018) menunjukkan bahwa motivasi kerja berpengaruh positif dan signifikan terhadap kinerja karyawan, maka motivasi ekstrinsik sebagai bagian dari motivasi kerja itu sendiri diyakini juga memiliki pengaruh yang positif dan signifikan terhadap kinerja karyawan.

$\mathrm{H}_{3}$ : Motivasi ekstrinsik berpengaruh positif dan signifikan terhadap kinerja karyawan PT Semen Padang, Jakarta Selatan

\section{Kerangka Analisis}

Kerangka analisis yang digunakan dalam penelitian ini, yaitu sebagai berikut.

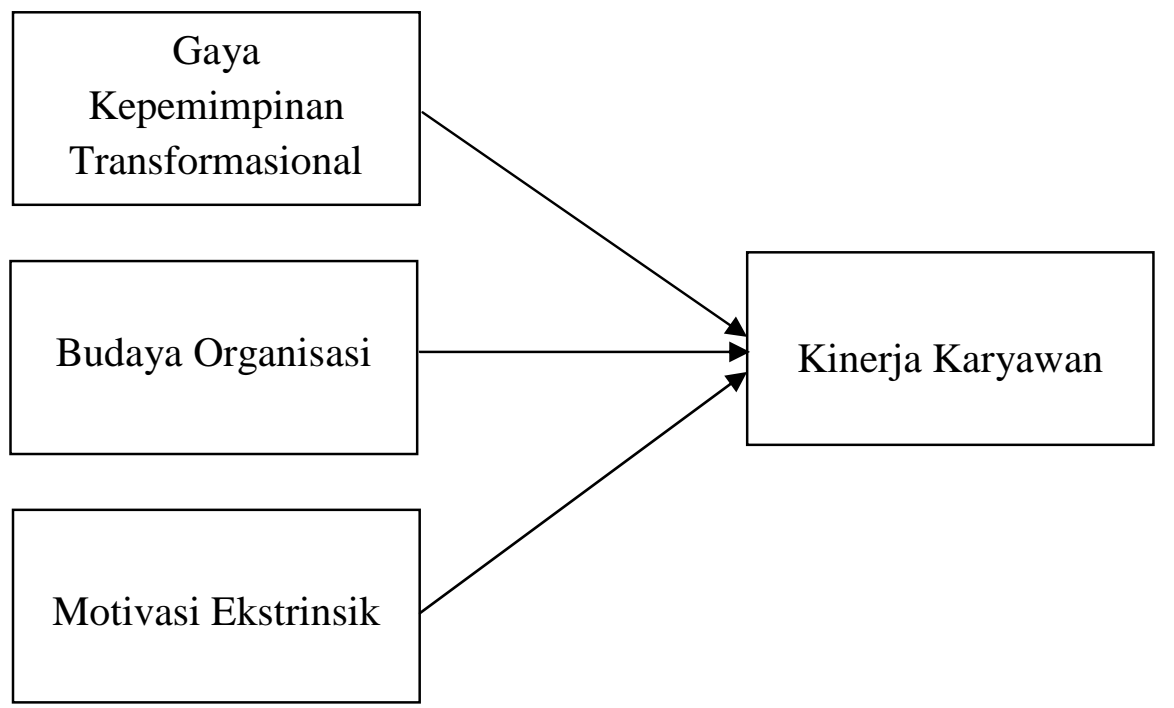

Gambar 1. Kerangka Analisis 


\section{METODOLOGI PENELITIAN}

\section{Jenis dan Sumber Data}

Data yang digunakan dalam penelitian ini adalah data cross section yang diperoleh dari sumber primer, yakni dari penyebaran kuesioner kepada sampel yang telah ditentukan.

\section{Populasi dan Sampel}

Populasi dalam penelitian ini adalah seluruh karyawan PT Semen Padang, Jakarta Selatan yang berjumlah 137 karyawan. Sampling dilakukan dengan menggunakan probability sampling method berjenis simple random sampling. Dengan menggunakan rumus Slovin, sampel yang digunakan dalam penelitian ini berjumlah 102 responden.

\section{Metode Analisis}

Analisis yang digunakan dalam penelitian ini adalah analisis inferensial dengan menggunakan regresi linear berganda untuk menganalisis pengaruh gaya kepemimpinan transformasional, budaya organisasi dan motivasi ekstrinsik terhadap kinerja karyawan PT Semen Padang, Jakarta Selatan.

\section{HASIL DAN PEMBAHASAN}

\section{Hasil Penelitian}

Instrumen penelitian ini diuji dengan menggunakan uji validitas dan reliabilitas. Hasil uji validitas menunjukkan bahwa instrumen penelitian ini terbukti valid karena memiliki $r_{\text {hitung }}$ yang lebih besar daripada $r_{\text {tabel-nya. Adapun hasil uji reliabilitas }}$ menunjukkan bahwa instrumen dari setiap variabel yang digunakan dalam penelitian ini terbukti reliabel karena memiliki nilai cronbach alpha yang lebih besar dari 0,6. Sementara itu, hasil uji asumsi klasik menunjukkan bahwa data penelitian terdistribusi normal, serta terbebas dari multikolinearitas, heteroskedastisitas dan autokorelasi.

Data yang telah memenuhi uji instrumen dan uji asumsik klasik tersebut kemudian diuji dengan menggunakan regresi linear berganda. Berdasarkan hasil regresi linear berganda, diperoleh persamaan sebagai berikut.

$$
Y=4,942+0,310 X_{1}+0,211 X_{2}+0,202 X_{3}
$$

Keterangan:

$$
\begin{array}{ll}
\mathrm{Y} & =\text { Kinerja karyawan } \\
\mathrm{X}_{1} & =\text { Gaya kepemimpinan transformasional } \\
\mathrm{X}_{2} & =\text { Budaya organisasi }
\end{array}
$$




\section{$\mathrm{X}^{3} \quad=$ Motivasi ekstrinsik}

Uji F menghasilkan nilai signifikansi sebesar 0,000 yang lebih kecil daripada 0,05, sehingga model penelitian ini terbukti layak karena gaya kepemimpinan transformasional, budaya organisasi dan motivasi ekstrinsik secara simultan berpengaruh signifikan terhadap kinerja karyawan.

Besarnya koefisien determinasi dari model penelitian ini adalah 0,262, sehingga gaya kepemimpinan transformasional, budaya organisasi dan motivasi ekstrinsik memberikan kontribusi sebesar 26,2\% dalam menjelaskan kinerja karyawan, sedangkan $73,8 \%$ sisanya dijelaskan oleh variabel-variabel lain yang tidak dianalisis dalam penelitian ini.

Hasil uji hipotesis dari penelitian ini disajikan dalam tabel sebagai berikut.

Tabel 1. Hasil Uji Hipotesis

\begin{tabular}{|l|c|c|c|}
\hline \multicolumn{1}{|c|}{ Variabel Independen } & t & Signifikansi & Keterangan \\
\hline Gaya kepemimpinan transformasional & 0,310 & 0,000 & Positif dan signifikan \\
\hline Budaya organisasi & 0,211 & 0,009 & Positif dan signifikan \\
\hline Motivasi ekstrinsik & 0,202 & 0,019 & Positif dan signifikan \\
\hline
\end{tabular}

(Sumber: Data diolah, 2018)

Berdasarkan tabel di atas, setiap variabel independen dalam penelitian ini, yaitu gaya kepemimpinan transformasional, budaya organisasi dan motivasi ekstrinsik secara parsial berpengaruh positif dan signifikan terhadap kinerja karyawan PT Semen Padang, Jakarta Selatan.

\section{Pembahasan}

\section{Pengaruh Gaya Kepemimpinan Transformasional terhadap Kinerja Karyawan}

Hasil penelitian ini menunjukkan bahwa gaya kepemimpinan transformasional berpengaruh positif dan signifikan terhadap kinerja karyawan PT Semen Padang, Jakarta Selatan. Hal tersebut membuktikan bahwa semakin baik gaya kepemimpinan transformasional yang diterapkan dalam suatu perusahaan, maka semakin baik pula kinerja karyawan perusahaan tersebut. Begitupun sebaliknya. Hal tersebut sejalan dengan temuan Mubarak dan Darmanto (2015), Subhi dan Yuniati (2014) serta Sugiono dan Pratista (2018).

Menurut Khan, et al., (2012), pemimpin dengan gaya kepemimpinan transformasional cenderung akan memberikan lebih banyak kesempatan bagi karyawannya untuk berkreasi melalui otonomi karena pemimpin dengan gaya ini cenderung lebih 
fleksibel daripada pemimpin dengan gaya kepemimpinan lainnya. Sugiono dan Pratista (2018) mengemukakan bahwa pemberian kesempatan yang lebih banyak kepada karyawan untuk berkreasi akan menyebabkan karyawan tersebut menjadi lebih mampu untuk menciptakan dan mengembangkan gagasannya untuk kepentingan perusahaan, sehingga karyawan tersebut akan memberikan kontribusi yang lebih besar kepada perusahaan tersebut. Akibatnya, kinerja karyawan tersebut pun akan mengalami peningkatan.

\section{Pengaruh Budaya Organisasi terhadap Kinerja Karyawan}

Hasil penelitian ini menunjukkan bahwa budaya organisasi berpengaruh positif dan signifikan terhadap kinerja karyawan PT Semen Padang, Jakarta Selatan. Hal tersebut membuktikan bahwa semakin baik budaya organisasi yang diterapkan dalam suatu perusahaan, maka semakin baik pula kinerja karyawan perusahaan tersebut. Begitupun sebaliknya. Hal tersebut sejalan dengan temuan Maharani dan Efendi (2017), Warni (2014), serta Suryadi dan Efendi (2018).

Sejalan dengan hasil penelitian ini, Sutrisno (2010) mengemukakan bahwa budaya yang dikelola dengan benar sebagai alat manajemen akan dapat mempengaruhi karyawan dan mendorongnya untuk bersikap positif, dedikatif dan produktif, sehingga meskipun nilai-nilai budaya tersebut tidak terlihat, tetapi keberadaannya merupakan kekuatan yang mengarahkan perilaku karyawan untuk berkinerja secara efektif.

\section{Pengaruh Motivasi Ekstrinsik terhadap Kinerja Karyawan}

Hasil penelitian ini menunjukkan bahwa motivasi ekstrinsik berpengaruh positif dan signifikan terhadap kinerja karyawan PT Semen Padang, Jakarta Selatan. Hal tersebut membuktikan bahwa semakin baik motivasi ekstrinsik yang diberikan kepada karyawan dalam suatu perusahaan, maka semakin baik pula kinerja karyawan yang dimaksud. Begitupun sebaliknya. Hal tersebut mendukung temuan Ayer, dkk., (2016), Rizwan et al. (2014), serta Sutanto dan Ariyanto (2018) yang menunjukkan bahwa motivasi kerja berpengaruh positif dan signifikan terhadap kinerja karyawan, dimana motivasi kerja itu sendiri diindikasikan oleh motivasi intrinsik dan ekstrinsik.

Oleh karena memiliki pengaruh yang positif dan signifikan terhadap kinerja karyawan, maka kurangnya pemberian motivasi ekstrinsik dapat menimbulkan masalah berupa kinerja karyawan yang rendah. Manullang (2001) mengemukakan bahwa apabila suatu perusahaan tidak memberikan motivasi ekstrinsik yang sepadan kepada karyawannya, misalnya dalam bentuk kondisi kerja, upah, tunjangan dan/atau jaminan 
keselamatan kerja yang memadai, maka tingkat kemangkiran karyawan yang bekerja di perusahaan tersebut pun akan mengalami peningkatan, sehingga kinerja karyawan yang dimaksud menjadi tidak optimal.

\section{KESIMPULAN DAN SARAN}

\section{Kesimpulan}

Berdasarkan hasil penelitian ini, dapat disimpulkan hal-hal sebagai berikut.

1. Gaya kepemimpinan transformasional berpengaruh positif dan signifikan terhadap kinerja karyawan PT Semen Padang, Jakarta Selatan.

2. Budaya organisasi berpengaruh positif dan signifikan terhadap kinerja karyawan PT Semen Padang, Jakarta Selatan.

3. Motivasi ekstrinsik berpengaruh positif dan signifikan terhadap kinerja karyawan PT Semen Padang, Jakarta Selatan.

\section{Saran}

Berdasarkan kesimpulan di atas, pimpinan di suatu perusahaan perlu senantiasa menerapkan gaya kepemimpinan transformasional yang baik dengan cara menginspirasi dan memotivasi karyawannya dalam rangka meningkatkan kinerja karyawan. Dalam memotivasi karyawan, perusahaan perlu membangun interpersonal relation yang baik dengan karyawan, memperhatikan dan menjamin terbangunnya interpersonal relation yang baik antarkaryawan itu sendiri, memberikan pengarahan yang baik kepada karyawan, menjamin keamanan kerja bagi karyawan, dan membangun lingkungan kerja yang nyaman dengan fasilitas yang memadai bagi karyawan. Selain itu, perusahaan juga perlu senantiasa menerapkan budaya organisasi yang baik untuk meningkatkan kinerja karyawannya, di antaranya dengan cara meningkatkan keterlibatan karyawan dalam pengambilan keputusan.

\section{DAFTAR PUSTAKA}

Ayer, J.E., L.R.J. Pangemanan dan Y.P.I. Rori. 2016. Pengaruh Motivasi dan Disiplin Kerja terhadap Kinerja Pegawai pada Dinas Pertanian Kabupaten Supiori. AgriSosio Ekonomi Unsrat. 12(3A): 27-46.

Bangun, W. 2012. Manajemen Sumber Daya Manusia. Erlangga. Jakarta.

Bass, B.M. dan B.J. Avolio. 1994. Improving Organizational Effectiveness through Transformational Leadership. Sage Publications. Thousand Oaks. 
Denison, D.R. 1990. Wiley Series on Organizational Assessment and Change: Corporate Culture And Organizational Effectiveness. John Wiley \& Sons. Oxford.

Hasibuan, M.S.P. 2012. Manajemen Sumber Daya Manusia. Bumi Aksara. Jakarta.

Khan, V., M.H. Hafeez, S.M.H. Rizvi, A. Hasnain, dan A. Mariam. 2012. Relationship of Leadership Styles, Employees Commitment and Organizatiion Performance: A Study on Customer Support Representatives. European Journal of Economics, Finance and Administrative Sciences. 49: 133-143.

Luthans, F. 2011. Organizational Behavior: An Evidence-Based Approach. McGraw-Hill. New York.

Maharani, I. 2017. Pengaruh Budaya Organisasi, Komitmen Organisasi, Kompensasi dan Etos Kerja terhadap Kinerja Pegawai Kementerian Ketenagakerjaan Republik Indonesia. Jurnal Ilmu Manajemen Oikonomia. 13(2): 49-61.

Malayu, S, P, H. 2012. Manajemen Sumber Daya Manusia. Bumi Aksara. Jakarta.

Mangkunegara, A.A.A.P.2011. Manajemen Sumber Daya Manusia Perusahaan. Remaja Rosdakarya Offset. Bandung.

Manullang, M. 2001. Manajemen Sumber Daya Manusia. BPFE. Yogyakarta.

Maulana, F.H., D. Hamid dan Y. Mayoan. 2015. Pengaruh Motivasi Intrinsik, Motivasi Ekstrinsik dan Komitmen Organisasi terhadap Kinerja Karyawan pada Bank BTN Kantor Cabang Malang. Jurnal Administrasi Bisnis. 22(1): 1-8.

Moeheriono. 2012. Pengukuran Kinerja Berbasis Kompetensi. Raja Grafindo Persada. Jakarta.

Mubarak, A. dan S. Darmanto. 2015. Pengaruh Gaya Kepemimpinan Transformasional dan Budaya Organisasi terhadap Kinerja Pegawai dengan Komitmen Organisasi sebagai Variabel Intervening: Studi pada PNS di Kecamatan Watukumpul Kabupaten Pemalang. Maksimum. 5(1): 1-16.

Pasolong, H. 2010. Teori Administrasi Publik. Alfabeta. Bandung.

Rivai, V. dan D. Mulyadi. 2012. Kepemimpinan dan Perilaku Organisasi. Edisi Ketiga. Raja Grafindo Persada. Jakarta.

Rizwan, M., M. Tariq, R. Hassan dan A. Sultan. 2014. A Comparative Analysis of the Factors Effecting the Employee Motivation and Employee Performance in Pakistan. International Journal of Human Resource Studies. 4(3): 35-49.

Robbins, S.P. dan T.A. Judge. 2006. Organizational Behavior. $12^{\text {th }}$ Ed. Prentice Hall. New Jersey. Terjemahan D. Angelica, R. Cahyani dan A. Rosyid. 2008. Perilaku Organisasi. Edisi 12. Salemba Empat. Jakarta. 
Sardiman, A.M. 2005. Interaksi dan Motivasi Belajar Mengajar. Raja Grafindo Persada. Jakarta.

Semen Padang. 2018. Sejarah Perusahaan. http://www.semenpadang.co.id/?mod=profil\& kat $=\& i d=1$. 30 Januari 2018 (21:37).

Subhi, E.R. dan T.Yuniati. 2014. Pengaruh Kepemimpinan Transformasional terhadap Kinerja Karyawan dengan Penghargaan sebagai Variabel Moderating. Jurnal Ilmu dan Riset Manajemen. 3(2): 1-18.

Sugiono, E. dan R.M. Pratista. 2018. Pengaruh Kepemimpinan Transformasional, Motivasi dan Lingkungan Kerja Fisik terhadap Kinerja Karyawan PT Rafa Topaz Utama. Jurnal Ilmu Manajemen Oikonomia. 14(2): 43-58.

Sunyoto, D. 2012. Manajemen Sumber Daya Manusia. Center for Academic Publishing Service. Jakarta.

Supandi. 2011. Menyiapkan Kesuksesan Anak Anda. Gramedia Pustaka Utama. Jakarta.

Suryadi, I. dan S. Efendi. 2018. Pengaruh Motivasi Intrinsik, Kepuasan Kerja dan Budaya Organisasi terhadap Kinerja Pegawai Biro Kepegawaian di Badan Kepegawaian Negara Jakarta. Jurnal Ilmu Manajemen Oikonomia. 14(2): 109-124.

Sutanto, P.H. dan E. Ariyanto. 2018. Pengaruh Disiplin dan Motivasi Kerja terhadap Kinerja Karyawan PT Fluid Indonesia. Jurnal Ilmu Manajemen Oikonomia. 14(1): 91-106.

Sutrisno, E. 2010. Manajemen Sumber Daya Manusia. Kencana Predana Media Grup. Jakarta.

Warni, E.D. 2014. Pengaruh Gaya Kepemimpinan dan Budaya Organisasi terhadap Kinerja Karyawan pada Sekretariat Daerah Kabupaten Temanggung. Jurnal Riset Manajemen Provesisa. 1(1): 64-77.

Yuk1, G. 2001. Leadership in Organization. Fifth Edition. Pearson. New Jersey. Terjemahan B. Supriyanto. 2010. Kepemimpinan dalam Organisasi. Edisi Kelima. Indeks. Jakarta. 